\title{
Xylitol production on sugarcane biomass hydrolysate by newly identified Candida tropicalis JA2 strain
}

\author{
Wilson G. Morais Junior (D) | Thályta F. Pacheco | Débora Trichez | João R.M. Almeida (D) | \\ Sílvia B. Gonçalves
}

Embrapa Agroenergia-Laboratory of Genetics and Biotechnology, Brasilia, DF, Brazil

Correspondence

João R. M. Almeida, Embrapa AgroenergiaLaboratory of Genetics and Biotecnology, Parque Estacao Biologica W3 Norte, Brasilia, DF 70770-901, Brazil.

Email: joao.almeida@embrapa.br;

jricardo13@yahoo.com.br

Funding information

Banco Nacional de Desenvolvimento

Econômico e Social; Conselho Nacional de Desenvolvimento Científico e Tecnológico; Brazilian Development Bank; Sugarcane

Technology Center

\begin{abstract}
Xylitol is a building block for a variety of chemical commodities, besides being widely used as a sugar substitute in the food and pharmaceutical industries. The aim of this work was to develop a microbial process for xylitol production using sugarcane bagasse hydrolysate as substrate. In this context, 218 non-Saccharomyces yeast strains were screened by growth on steam-exploded sugarcane bagasse hydrolysate containing a high concentration of acetic acid $(8.0 \mathrm{~g} / \mathrm{L})$. Seven new Candida tropicalis strains were selected and identified, and their ability to produce xylitol on hydrolysate at low $\mathrm{pH}$ (4.6) under aerobic conditions was evaluated. The most efficient strain, designated $C$. tropicalis JA2, was capable of producing xylitol with a yield of $0.47 \mathrm{~g} / \mathrm{g}$ of consumed xylose. To improve xylitol production by $C$. tropicalis JA2, a series of experimental procedures were employed to optimize $\mathrm{pH}$ and temperature conditions, as well as nutrient source, and initial xylose and inoculum concentrations. C. tropicalis JA2 was able to produce $109.5 \mathrm{~g} / \mathrm{L}$ of xylitol with a yield of $0.86 \mathrm{~g} / \mathrm{g}$ of consumed xylose, and with a productivity of $2.81 \mathrm{~g} \cdot \mathrm{L} \cdot \mathrm{h}$, on sugarcane bagasse hydrolysate containing $8.0 \mathrm{~g} / \mathrm{L}$ acetic acid and177 $\mathrm{g} / \mathrm{L}$ xylose, supplemented with $2.0 \mathrm{~g} / \mathrm{L}$ yeast nitrogen base and $4.0 \mathrm{~g} / \mathrm{L}$ urea. Thus, it was possible to identify a new $C$. tropicalis strain and to optimize the xylitol production process using sugarcane bagasse hydrolysate as a substrate. The xylitol yield on biomass hydrolysate containing a high concentration of acetic acidobtained in here is among the best reported in the literature.
\end{abstract}

\section{KEYWORDS}

Candida tropicalis, fermentation, sugarcane biomass hydrolysate, xylitol

\section{1 | INTRODUCTION}

In recent years, there has been a considerable increase in studies seeking more efficient uses of agro-industrial residues for production of fuels and chemicals (Rocha, Rodrigues, Albuquerque, Gonçalves, \& Macedo, 2014). Among several alternative uses of hexose and pentose sugars present in lignocellulosic hydrolysates, production of xylitol has been widely investigated (Albuquerque, Gomes, Marques, Silva, \&
Rocha, 2015). Xylitol is a pentose sugar alcohol with important applications because of its strong sweetening properties and capacity to inhibit microbial growth, as well as for its low calorie content, and lack of carcinogenic and cariostatic properties. It has been widely used as a replacement for sucrose in the food and pharmaceutical industries (Aguirre-Zero, Zero, \& Proskin, 1993; Imark, Canisag, Vokoun, \& Meryemoglu, 2017; Lynch \& Milgrom, 2003; Ronda, Gómez, Blanco, \& Caballero, 2005). In addition, xylitol is considered one of the 12 
major high added-value intermediates that can be produced from biomass, due to it is being a building block for a variety of basic chemicals (Werpy \& Petersen, 2004).

Xylitol is industrially produced by catalytic hydrogenation of pure xylose solution under high temperature and pressure (Dasgupta Bandhu, Adhikari, \& Ghosh, 2017). This production process is expensive and presents low yields due to the complexity of the product recovery stages (Bier, Maranho, Azevedo, \& da Silva, 2007). Alternatively, biochemical production processes have been extensively evaluated using different microorganisms and substrates such as vegetable waste (Zhang, Geng, Yao, Lu, \& Li, 2012), bamboo (Miura et al., 2013), corncob (Cheng et al., 2009; Hongzhi, Keke, Jingping, \& Wenxiang, 2011; Ping, Ling, Song, \& Ge, 2013; Rodrigues, Kenealy, \& Jeffries, 2011), and sugar cane bagasse (Arruda, Rodrigues, Silva, \& Felipe, 2011; Prakash, Varma, Prabhune, Shouche, \& Rao, 2011). Fermentative processes have gained attention due to the possibility of using yeasts to produce xylitol with yields as high as $85 \%$ of theoretical maximum (Bier et al., 2007).

The major drawback of microbial production processes employing lignocellulosic-derived hydrolysates is the presence of inhibitory compounds in their composition, which may hinder yeast metabolism (Dasgupta et al., 2017). During pretreatment and hydrolysis of biomass, cellulose and hemicellulose are broken down, releasing monomeric sugars but also microbial-inhibitory compounds, such as furaldehydes, phenolic compounds, and acetic acid (Almeida et al., 2007; Kumar \& Sharma, 2017). The composition and concentration of inhibitors vary depending on process conditions and biomass source. However, acetic acid is inherent to biomass hydrolysis conditions, as it is formed by deacetylation of hemicelluloses. This acid is a weak monocarboxylic acid (pKa 4.76) that shows antimicrobial effects mainly at low $\mathrm{pH}$ values (below pKa). Acetate penetrates the cell in its undissociated form, but once inside the cytoplasm, it dissociates, triggering high energy demand and an increase in cytoplasmic pH values (Hahn-Hägerdal, Karhumaa, Fonseca, SpencerMartins, \& Gorwa-Grauslund, 2007; Sousa, Ludovico, Rodrigues, Leão, \& Côrtes-Real, 2012). In addition, it is capable of inhibiting yeast xylose metabolism (decreasing xylose reductase activity), and even at relatively low concentrations $(5.4 \mathrm{~g} / \mathrm{L})$ it strongly inhibits xylitol production by Candida tropicalis (Rafiqul, Sakinah, \& Zularisam, 2015). Thus, identification of microorganisms with higher tolerance to inhibitors, especially acetic acid, is essential for the development of an efficient xylitol production process (Bazoti et al., 2017; Xu \& Hanna, 2010).

Yeast species from the Candida, Pichia, Debaryomyces, Kluyveromyces, and Spathaspora genera have been evaluated for xylitol production from biomass hydrolysates. Among these, Candida species have shown good performance with production yields varying from $19 \%$ to $72 \%$ of the theoretical maximum (Carvalheiro, Duarte, Medeiros, \& Gírio, 2007; García-Diéguez, Salgado, Roca, \& Domínguez, 2001; Miura et al., 2013; Rocha et al., 2014; Rodrigues et al., 2011; Zhang et al., 2012). C. tropicalis has shown good performance on lignocellulosic hydrolysates from corncob (Cheng et al., 2009; Guo et al., 2013; Ling, Cheng, Ge, \& Ping, 2011; Misra, Raghuwanshi, \& Saxena, 2013; Wang et al., 2011), rice straw (Liaw, Chen, Chang, \& Chen,
2008), and sugarcane bagasse (Rao, Jyothi, Prakasham, Sarma, \& Rao, 2006). The best reported value for xylitol production by C. tropicalis strains on sugarcane bagasse hydrolysate was $81.6 \mathrm{~g} / \mathrm{L}$ of xylitol, with a yield of $0.57 \mathrm{~g} / \mathrm{g}$ and productivity of $0.68 \mathrm{~g} / \mathrm{g} \mathrm{h}$ (Vallejos et al., 2016). However, under the conditions evaluated, the maximum acetic acid concentration was $1.39 \mathrm{~g} / \mathrm{L}$ (Albuquerque et al., 2015). Although C. tropicalis is considered an opportunistic pathogen, the U.S. Food and Drug Administration has allowed its use for xylitol production (De Mello Lourenço, Dini-Andrade, Aguilar-Vildoso, \& Basso, 2014).

In the current work, a collection of xylose-assimilating yeasts was screened for their ability to grow on sugarcane biomass hydrolysate. A strain with high tolerance towards hydrolysate was isolated and identified as C. tropicalis JA2. Subsequently, the xylitol production processed by this yeast was optimized through a series of experimental procedures in order to determine best $\mathrm{pH}$ and temperature conditions, as well as nutrient source, inoculum size, and substrate concentrations. Finally, a xylitol production process with high productivity and yield based on C. tropicalis JA2 and sugarcane biomass hydrolysate was obtained.

\section{2 | MATERIAL AND METHODS}

Yeast strains were kept in yeast peptone dextrose (YPD) composed of $10 \mathrm{~g} / \mathrm{L}$ yeast extract, $10 \mathrm{~g} / \mathrm{L}$ bacteriological peptone, and $20 \mathrm{~g} / \mathrm{L}$ dextrose, or yeast peptone xylose (YPX) composed of $10 \mathrm{~g} / \mathrm{L}$ yeast extract, $10 \mathrm{~g} / \mathrm{L}$ bacteriological peptone, and $20 \mathrm{~g} / \mathrm{L}$ xylose. In addition, minimal medium, yeast nitrogen base $6.7 \mathrm{~g} / \mathrm{L}$ (YNB), was supplemented with $60 \mathrm{~g} / \mathrm{L}$ xylose. When different concentrations of sugar were required, the value was specified appropriately.

The sugarcane bagasse hydrolysate, kindly provided by the Sugarcane Technology Center (CTC), São Paulo, Brazil, was obtained by steam explosion followed by acid hydrolysis of the hemicelluloserich fraction. For each pretreatment batch, $8 \mathrm{~kg}$ of raw material (sugarcane bagasse) was processed in a steam explosion system for $8 \mathrm{~min}$ at $15 \mathrm{kgf} / \mathrm{cm}^{2}$ (equivalent to $197.85^{\circ} \mathrm{C}$ ), with $50 \%$ humidity. For the breakdown of the oligomers, the liquid fraction of the steam explosion was subjected to hydrolysis with $0.5 \% \mathrm{H}_{2} \mathrm{SO}_{4}(\mathrm{w} / \mathrm{w})$ at $130^{\circ} \mathrm{C}$ for $100 \mathrm{~min}$. The final composition of the hydrolysate was (g/L):cellobiose, 2.21; glucose, 5.40; xylose, 90.32; acetic acid, 19.41; furfural, 2.93; and hydroxymethylfurfural (HMF), 0.54. This batch of hydrolysate was employed in all experiments described in this study, except in the experiment otherwise indicated. A second batch of hydrolysate was prepared following the same conditions employed before, and its composition was ( $\mathrm{g} / \mathrm{L}$ ): cellobiose, 2.14; glucose, 4.96; xylose, 80.6; acetic acid, 19.62; furfural, 2.2; and hydroxymethylfurfural (HMF) 0.36 .

\section{1 | Screening of yeast strains}

The 218 non-Saccharomycesyeast strains used in this work belong to the "Collection of Microorganisms and Microalgae Applied to 
Agroenergy and Biorefining" from Embrapa Agroenergia. The yeast strains were previously isolated from soil and decaying wood samples collected in Brazilian Cerrado, and from fermentation broth in sugarcane mills. Their ability to grow on minimal medium supplemented with xylose as the sole carbon source was previously determined (unpublished data). In addition, the diversity among the 218 species was analyzed by sequencing of the D1/D2 region in some strains, and the following species were identified: Cyberlindnerafabianii, Wickerhamomycesanomalus, Kluyveromyces marxianus, Spathaspora brasiliensis, Meyerozyma guilliermondii, and Hanseniasporauvarum.

In order to identify strains with a high xylose consumption rate and tolerance to sugarcane biomass hydrolysate, a serial screening in minimal medium and hydrolysate was performed. Initially, each purified strain was grown in $200 \mu \mathrm{L}$ of $10 \% \mathrm{YPX}$ medium $(10 \mathrm{~g} / \mathrm{L}$ yeast extract, $20 \mathrm{~g} / \mathrm{L}$ bacteriological peptone and $100 \mathrm{~g} / \mathrm{L}$ xylose) at $30^{\circ} \mathrm{C}$ for $24 \mathrm{hr}$ in 96 -well microtiter plates on a rotating incubator at $200 \mathrm{rpm}$. After this, all 218 yeast strain suspensions were transferred to Erlenmeyer flasks (1 L) containing $400 \mathrm{ml}$ of defined medium $(6.7 \mathrm{~g} / \mathrm{L}$ of yeast nitrogen base (YNB) and $100 \mathrm{~g} / \mathrm{L}$ of xylose), which was incubated under the same conditions as the preculture for $48 \mathrm{hr}$. A second and third cycles of cultivation were carried out by inoculating the same fresh minimal medium with $10 \%$ of the previous culture. Cycles 4, 5, and 6 were performed under the same conditions, except that the minimal medium was supplemented with $15 \%, 30 \%$, and $45 \%(\mathrm{v} / \mathrm{v})$ sugarcane bagasse hydrolysate, respectively. Samples were taken at the end of each cycle for metabolite quantification.

After Cycle 6, the cultures were diluted and plated on YPD agar medium for isolation of single colonies. The plates were incubated at $30^{\circ} \mathrm{C}$ for $48 \mathrm{hr}$ and morphologically different colonies were isolated.

The selected yeasts were deposited in the Collection of Microorganisms of Agricultural and Environmental Importance (CMAA) of the Brazilian Agriculture Research Corporation-EMBRAPA, located in Jaguariúna, Brazil. This collection is registered in the Culture Collection Information Worldwide of the World Data Centre for Microorganisms. The accession number is CMAA1716.

\section{2 | Yeast taxonomy}

Selected yeast strains were grown in $5 \mathrm{ml}$ of $\mathrm{YPD}$, at $28^{\circ} \mathrm{C}$ for $20 \mathrm{hr}$, and afterwards genomic DNA (gDNA) was extracted using the PureLink Genomic DNA Kit (Invitrogen), following the manufacturer's instructions. The D1/D2 region from the large-subunit of the rRNA gene was amplified by polymerase chain reaction using primers NL1 (5'-GCATATCAATAAGCGgAGGAAAAG-3') and NL4 (5'-GGTCCG TGTTTCAAGACGG-3'; Kurtzman \& Robnett, 1998) and gDNA as template.

Amplified DNA was purified and submitted to DNA sequencing at Eurofins Genomics (Louisville, KY, United States). Sequences were aligned, and the consensus sequences were compared with other yeast sequences deposited in GenBank with the following accession numbers: MH230894 (6.2), MH230895 (6.3), MH230896
(6.4), $\mathrm{MH} 230897$ (6.5), $\mathrm{MH} 230898$ (6.6), $\mathrm{MH} 230899$ (6.7) e $\mathrm{MH} 229983$ (6.8).

\section{3 | Optimization of fermentation}

\subsection{1 | Preculture procedure}

Single yeast colonies were propagated in $400 \mathrm{ml}$ (1-L flask) of YPX $(100 \mathrm{~g} / \mathrm{L})$ and incubated at $30^{\circ} \mathrm{C}$ for $72 \mathrm{hr}$ in a rotating incubator at $200 \mathrm{rpm}$. Afterwards, the cells were separated by centrifugation at 4,000 g for $5 \mathrm{~min}$.

The inoculum concentration was quantified by dry weight analysis. Samples were added to predried $\left(105^{\circ} \mathrm{C}\right.$ in oven, $\left.30 \mathrm{~min}\right)$ and preweighed glass pads and then dried at $80^{\circ} \mathrm{C}$ overnight in a convection oven. Before determining the final weight after drying using an analytical balance, the glass pads and samples were cooled in a desiccator. The loss of weight was calculated as grams of dry weight per liter.

\subsection{2 | Fermentation of biomass hydrolysate}

After the screening and taxonomy steps, seven strains were tested for tolerance on sugarcane biomass hydrolysate, xylose consumption, and xylitol production. For this, $8.0 \mathrm{~g} / \mathrm{L}$ of each strain was inoculated separately (with viability greater than $92 \%$ ) into 125 -ml Erlenmeyer flasks containing $40 \mathrm{ml}$ of medium composed of sugarcane bagasse hydrolysate (described in Section 2), diluted to $40 \%(\mathrm{v} / \mathrm{v})$. The final hydrolysate-fermentation medium contained YNB (6.7 g/L), xylose (75 g/L), glucose (12 g/L), and acetic acid (7.8 g/L), at pH 4.6. The $\mathrm{pH}$ value of biomass hydrolysate of sugarcane was adjusted with calcium hydroxide. The experiments were carried out at $30^{\circ} \mathrm{C}$ under stirring in a rotating incubator at $180 \mathrm{rpm}$. Samples were withdrawn periodically for biomass and metabolite quantification.

\subsection{3 | Plackett-Burman experimental design for salts and nitrogen sources}

To determine which salts and nitrogen sources are required to improve the xylose consumption rate and xylitol production, a Plackett-Burmam (PB) design with 16 trials was used to screen the medium components. The design included 11 input variables and three replicates at the central point (Plackett \& Burmam, 1946; Rodrigues \& lemma, 2012). The medium salts components and their respective ranges were $\mathrm{KH}_{2} \mathrm{PO}_{4}$ from 0.0 to $4.0 \mathrm{~g} / \mathrm{L}, \mathrm{MgSO}_{4}$ from 0.0 to $2.0 \mathrm{~g} / \mathrm{L},\left(\mathrm{NH}_{4}\right)_{2} \mathrm{SO}_{4}$ from 0.0 to $4.0 \mathrm{~g} / \mathrm{L}, \mathrm{ZnSO}_{4}$ from 0.0 to $1.0 \mathrm{~g} / \mathrm{L}, \mathrm{MnSO}_{4}$ from 0.0 to $1.0 \mathrm{~g} / \mathrm{L}, \mathrm{Fe}_{2} \mathrm{SO}_{4}$ from 0.0 to $0.8 \mathrm{~g} / \mathrm{L}, \mathrm{NaCl}$ from 0.0 to $1.0 \mathrm{~g} / \mathrm{L}, \mathrm{CuSO}_{4}$ from 0.0 to $0.1 \mathrm{~g} / \mathrm{L}$. For the nitrogen sources, the ranges were yeast extract from 0.0 to $5.0 \mathrm{~g} / \mathrm{L}$, YNB from 2.0 to $4.0 \mathrm{~g} / \mathrm{L}$, and urea from 0.0 to $2.0 \mathrm{~g} / \mathrm{L}$.

All fermentations were carried out using $8.0 \mathrm{~g} / \mathrm{L}$ (dry weight) of $C$. tropicalis JA2 cells with viability greater than $94 \%$, inoculated into $40 \mathrm{ml}$ (125-ml flasks) of medium containing $40 \%$ sugarcane biomass hydrolysate, with final concentration of $40 \mathrm{~g} / \mathrm{L}$ xylose and 
$12 \mathrm{~g} / \mathrm{L}$ glucose. The medium was supplemented with nutrients according to the PB design with 16 trials. The experiments were carried out at $30^{\circ} \mathrm{C}$ under stirring in a rotating incubator at $180 \mathrm{rpm}$. Samples were withdrawn periodically for biomass and metabolite quantification.

\subsection{4 | Effect of $\mathrm{pH}$ on xylitol production}

In order to evaluate the effect of $\mathrm{pH}$ on xylitol production, the $\mathrm{pH}$ of the fermentation medium was adjusted to 4.6, 5.5, 6.0, 6.4, and 7.0 with calcium hydroxide. Based on the PB results, the medium composition was adjusted to $40 \%$ sugarcane biomass hydrolysate supplemented with $1.0 \mathrm{~g} / \mathrm{L}$ of $\left(\mathrm{NH}_{4}\right)_{2} \mathrm{SO}_{4}, 5.0 \mathrm{~g} / \mathrm{L}$ of yeast extract, $4.0 \mathrm{~g} / \mathrm{L}$ of $\mathrm{YNB}$, and $0.8 \mathrm{~g} / \mathrm{L}$ of urea, with xylose and glucose concentration of 50.0 and $8.0 \mathrm{~g} / \mathrm{L}$, respectively. All other fermentation parameters were the same as those described in Section 2.3.3. Each experiment was carried out in triplicate. Samples were withdrawn periodically for biomass and metabolite quantitation.

\subsection{5 | Optimization using central composite design}

Central composite design (CCD) was used to optimize xylitol production by $C$. tropicalis JA2 by evaluating different concentrations of supplementary nutrients that significantly affected xylitol production according to PB (Section 2.2.3). Thus, the first CCD (central composite design 1) with four variables and three replicates at central point was applied to optimize the xylitol production after $39 \mathrm{hr}$. Twenty-seven experiments were conducted. The alpha value used for orthogonality was 2.0.

The independent variables considered were $\left(\mathrm{NH}_{4}\right)_{2} \mathrm{SO}_{4}$ from 0 to $6.0 \mathrm{~g} / \mathrm{L}\left(\mathrm{X}_{1}\right)$, yeast extract from 0 to $10.0 \mathrm{~g} / \mathrm{L}\left(\mathrm{X}_{2}\right)$, YNB from 2.0 to $7.0 \mathrm{~g} / \mathrm{L}\left(\mathrm{X}_{3}\right)$, and urea from 0 to $4.0 \mathrm{~g} / \mathrm{L}\left(\mathrm{X}_{4}\right)$.

Fermentations were carried out with $8.0 \mathrm{~g} / \mathrm{L}$ (dry weight) of C. tropicalis cells (with viability greater than 94\%), inoculated into $40 \mathrm{ml}$ (in 125-ml flasks) of medium containing $40 \%$ sugarcane biomass hydrolysate, supplemented with $40 \mathrm{~g} / \mathrm{L}$ xylose and $8.0 \mathrm{~g} / \mathrm{L}$ of glucose, at $\mathrm{pH}$ 6.4. The experiments were carried out at $30^{\circ} \mathrm{C}$ and $180 \mathrm{rpm}$ in a rotating incubator.

After optimization of composition and nutrient concentration in the medium, two new CCDs were performed to evaluate the effects of initial xylose and yeast concentration on the fermentation medium and operating temperature. The responses analyzed were xylose consumption and xylitol production after $39 \mathrm{hr}$. A sequential strategy was used for the second and third CCDs, with 17 experiments conducted in each CCD, and for both, the alpha value used for orthogonality was 1.68 .

For CCD2, we considered the independent variables of initial xylose from 50 to $150 \mathrm{~g} / \mathrm{L}\left(\mathrm{X}_{1}\right)$, inoculum concentration from 5 to $25 \mathrm{~g} / \mathrm{L}\left(\mathrm{X}_{2}\right)$, and operating temperature from 25 to $40^{\circ} \mathrm{C}\left(\mathrm{X}_{3}\right)$.

CCD3 was constructed having as a central point the conditions that maximize xylitol production as determined in the second $C C D$ (CCD2). For CCD3, we considered the independent variables of initial xylose from 80 to $220 \mathrm{~g} / \mathrm{L}\left(\mathrm{X}_{1}\right)$, inoculum concentration from 10 to $40 \mathrm{~g} / \mathrm{L}\left(\mathrm{X}_{2}\right)$, and operating temperature from 25 to $55^{\circ} \mathrm{C}\left(\mathrm{X}_{3}\right)$.

The fermentations were carried out in $125-\mathrm{ml}$ flasks with $40 \mathrm{ml}$ of medium containing $40 \%$ sugarcane biomass hydrolysate with glucose concentration at $8 \mathrm{~g} / \mathrm{L}$, cellobiose $(0.88 \mathrm{~g} / \mathrm{L})$, acetic acid $(7.76 \mathrm{~g} / \mathrm{L})$, furfural $(1.17 \mathrm{~g} / \mathrm{L})$, and HMF $(0.22 \mathrm{~g} / \mathrm{L})$. The medium was supplemented with YNB (2 g/L) and urea $(4 \mathrm{~g} / \mathrm{L})$, at $\mathrm{pH}$ 6.4. The experiments were carried out by incubating the flasks under stirring in a rotating incubator at $180 \mathrm{rpm}$.

Finally, the yeast performance was evaluated under the optimized fermentation conditions in nondiluted hydrolysate. A fermentation experiment employing the same conditions described above was carried out with $100 \%$ sugarcane biomass hydrolysate (second batch with composition described in Section 2). To minimize any dilution of hydrolysate, it was only supplemented with $0.32 \mathrm{~g}$ of YNB (to reach $2 \mathrm{~g} / \mathrm{L}$ ) and $0.64 \mathrm{~g}$ urea (to reach $4 \mathrm{~g} / \mathrm{L}$ ) and yeast biomass. The experiment was carried out in triplicate.

\subsection{6 | Statistical analysis}

The statistical analysis of experimental data obtained in the PB and CCD were performed using the software STATISTICA 12.0. Due to the variability of the bioprocesses, a significance level of $90 \%(p<.1)$ was considered (Haaland, 1989). To validate the model predictions, fermentations were carried out under conditions predicted by the models.

\section{4 | Metabolite and biomass quantification}

Samples from fermentation experiments were centrifuged at $16,873 \mathrm{~g}$ for $10 \mathrm{~min}$, and the supernatant was used in quantification. Acetic acid, glucose, xylose, xylitol, and ethanol were quantified by HPLC (Agilent-1260 Infinity) coupled with an index detector RID 10-A using a reverse-phase column (Aminex ${ }^{\circledR} \mathrm{HPX} 87 \mathrm{H}$, BioRad). Products were eluted using a solution of $5 \mathrm{mM} \mathrm{H}_{2} \mathrm{SO}_{4}$ as mobile phase at $0.6 \mathrm{ml} / \mathrm{min}$ flow rate at $45^{\circ} \mathrm{C}$. The concentrations of compounds were determined using calibration curves, and values were calculated from peak areas.

Yeast concentration was monitored by optical density at $605 \mathrm{~nm}$ and correlated with dry weight. The dry cell weight was calculated according to optical density using the following linear correlation: Concentration $(\mathrm{g} / \mathrm{L})=$ dilution $\times 0.518 \times \mathrm{OD}_{605}$. The correlation coefficient $R^{2}$ was 0.998 . Yeast viability was determined by counting cells stained with erythrosine $B$ in a Neubauer chamber using optical microscopy.

\section{3 | RESULTS AND DISCUSSION}

\section{1 | Yeast selection and identification}

To isolate a yeast strain able to efficiently metabolize xylose in the presence of biomass hydrolysate with a high concentration of 
acetic acid (8.0 g/L), 218 yeast strains were screened for growth on defined medium (DM) and on medium supplemented with sugarcane bagasse hydrolysate. Initially, all strains were inoculated in $10 \%$ YPX (xylose, $100 \mathrm{~g} / \mathrm{L}$ ) medium, and after $48 \mathrm{hr}$ of growth, they were transferred to fresh medium. After six cycles of cultivation (three in DM and three in increasing concentrations of hydrolysate), the xylose-consuming yeasts were isolated on agar plates containing $2 \%$ YPX (xylose, $20 \mathrm{~g} / \mathrm{L}$ ). Thus, seven different colonies, named as 6.2, 6.3, 6.4, 6.5, 6.6, 6.7, and 6.8, were picked for taxonomic identification and physiological characterization.

For molecular identification, the D1/D2 domain of the largesubunit rRNA gene was amplified by polymerase chain reaction and submitted for sequencing. Analysis of these sequences showed that all strains belong to the $C$. tropicalis species. These results indicate the efficiency of $C$. tropicalis strains in growth on xylose, either in defined or hydrolysate-containing medium. However, some differences could be noted among the seven strains. Strain 6.2 showed an identical sequence to $C$. tropicalis isolate GX06 (accession number MF148900.1), whereas one indel was observed in the 6.6 and 6.7 strain sequences. Strain 6.8 differs in the D1/D2 sequence by a twonucleotide deletion compared with the same $C$. tropicalis strain. The D1/D2 sequences from the 6.3 and 6.5 strainswere, respectively, $100 \%$ and $99 \%$ identical to C. tropicalis isolate NBT8 (accession number MF461173.1), whereas the 6.4 sequencewas identical to C. tropicalis strain SA-1 (accession number JN185908.1).

The analyses of xylose reductase activity with NADH and NADPH in the selected C. tropicalisstrain JA2 was carried out by Trichez, Steindorff, Soares, Formighieri, and Almeida (2018), and the results showed that the xylose reductase (XR) activity was strictly NADPHdependent. High XR activities improve the rate of xylose consumption and when associated with dependence on the NADPH cofactor, they favor the production of xylitol (Cadete et al., 2016; Karhumaa, Garcia-Sanchez, Hahn-Hägerdal, \& Gorwa-Grauslund, 2007).

\section{2 | Fermentation of sugarcane biomass hydrolysate by the isolated yeast strains}

The fermentation capacities of the seven new $C$. tropicalis strains were evaluated in medium containing sugarcane biomass hydrolysate. Fermentation assays were carried out under aerobic conditions, in medium containing $8.0 \mathrm{~g} / \mathrm{L}$ of acetic acid with an initial $\mathrm{pH}$ of 4.6 . All yeasts were able to grow on the hydrolysate. After $65 \mathrm{hr}$ of cultivation, growth was similar for the seven strains $(p<.05$; Figure 1). The 6.8 strain was the most efficient xylose-consuming strain $(49.1 \pm 0.89 \mathrm{~g} / \mathrm{L})$ and the most efficient producer of xylitol $(22.16 \pm 1.47 \mathrm{~g} / \mathrm{L})$ and ethanol $(6.9 \pm 0.73 \mathrm{~g} / \mathrm{L})$. On the other hand, the yeast 6.7 consumed only $22.9 \pm 0.66 \mathrm{~g} / \mathrm{L}$ of xylose the lowest in comparison with the other strains, producing $12.5 \pm 0.51 \mathrm{~g} / \mathrm{L}$ xylitol and $5.3 \pm 0.09 \mathrm{~g} / \mathrm{L}$ ethanol. The other five strains showed similar performances, consuming approximately $45 \mathrm{~g} / \mathrm{L}$ of xylose (Figure 1). These results indicate that although the strains belong to the same species, they showed significantly different hydrolysate fermentation capabilities. These results are in good agreement with previous observations that different yeast strains respond distinctly in presence of hydrolysate (Almeida, Karhumaa, Bengtsson, \& Gorwa-Grauslund, 2009).

The xylose consumption rate, and xylitol production and yield, varied significantly among the strains $(p<.05)$. Strain 6.8 showed the highest xylose consumption rate $(0.77 \pm 0.02 \mathrm{~g} \cdot \mathrm{L} \cdot \mathrm{h})$ and the highest xylitol yield $0.45 \pm 0.01 \mathrm{~g} / \mathrm{g}$ consumed xylose, whereas the strain 6.7 showed the lowest values for xylose consumption

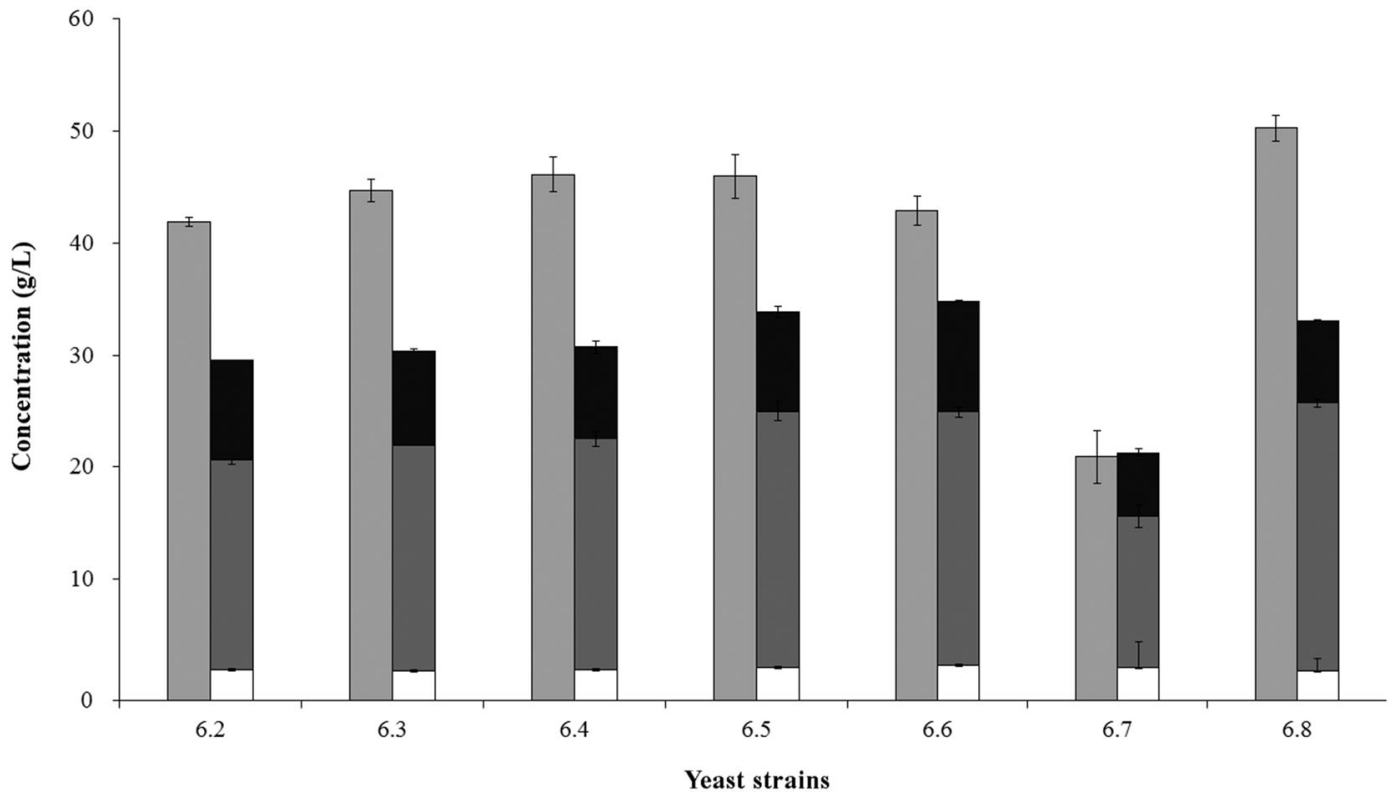

FIGURE 1 Cell growth (OD), xylose consumption and product formation after $65 \mathrm{hr}$ of fermentation in medium containing sugarcane biomass hydrolysate. ( $\square$ ) Biomass, $(\square)$ xylose consumed, $(\square)$ xylitol, and $(\square)$ ethanol. Experiments were performed in triplicate and standard errors are less than $5 \%$ 
rate and xylitol yield. Despite the low cell density and relatively high concentration of acetic acid in these experiments, the xylitol yields described here are superior to values reported in other studies with C. tropicalis. Mateo, Puentes, and Moya (2015) used C. tropicalis NBRC 0618 , achievinga xylitol yield of $0.23 \mathrm{~g} / \mathrm{g}$ of consumed xylose in the fermentation of acid hydrolysate from olive pruning. Swain and Krishnan (2015) reached a xylitol production yield of $0.19 \mathrm{~g} / \mathrm{g}$ of consumed xylose using $C$. tropicalis in the fermentation of rice straw. However, higher xylitol concentration $(16.2 \mathrm{~g} / \mathrm{L})$ and yield $(0.67 \mathrm{~g} / \mathrm{g})$ values were obtained by fermentation of $C$. guilliermondii in medium supplemented with sugarcane straw (Hernández-Perez, Arruda, \& Felipe, 2016)

Based on the obtained results of higher xylose consumption rate and xylitol yield, strain 6.8 was named $C$. tropicalis JA2 and was chosen for optimization of xylitol production.

\section{3 | Plackett-Burman design for xylitol production}

As C. tropicalis JA2 was able to produce xylitol in the presence of sugarcane hydrolysate containing a considerable amount of acetic acid, we aimed to improve the yeast performance by optimizing the fermentation medium. Thus, a Plackett and Burman (PB) design was performed to analyze the influence of the salts $\mathrm{KH}_{2} \mathrm{PO}_{4}, \mathrm{MgSO}_{4}$, $\left(\mathrm{NH}_{4}\right)_{2} \mathrm{SO}_{4}, \mathrm{ZnSO}_{4}, \mathrm{MnSO}_{4}, \mathrm{Fe}_{2} \mathrm{SO}_{4}, \mathrm{NaCl}$, and $\mathrm{CuSO}_{4}$, and the nitrogen sources urea, yeast extract, and YNB in medium at an initial $\mathrm{pH}$ of 4.6.

The effect of each variable on the dependent variable xylitol production was evaluated after $39 \mathrm{hr}$ of fermentation (Table 1). Considering statistical significance of $p<.1$, in the concentration range evaluated, $\left(\mathrm{NH}_{4}\right)_{2} \mathrm{SO}_{4}$, yeast extract, $\mathrm{YNB}$, and urea had a significant positive effect, indicating that it is possible to increase xylitol production by $C$. tropicalis JA2. On other hand, $\mathrm{Fe}_{2} \mathrm{SO}_{4}, \mathrm{MnSO}_{4}$, $\mathrm{CuSO}_{4}$, and $\mathrm{KH}_{2} \mathrm{PO}$ had a significant negative effect, indicating

TABLE 1 Estimated effect, regression coefficient, and corresponding $t$ and $p$ values for xylitol concentration in $39 \mathrm{hr}$ of fermentation in Plackett-Burman (PB) design experiment

\begin{tabular}{lrllll} 
Factor & Effect & Coefficient & Std. Error & $t$ value & $p$ value \\
\hline Mean/Interc. & 59.481 & 59.481 & 0.0789 & 753.514 & 0.00000 \\
\hline Urea & 19.108 & 0.9554 & 0.0860 & 111.064 & 0.00001 \\
\hline Yeast Ext. & 13.150 & 0.6575 & 0.0860 & 76.433 & 0.00012 \\
\hline $\mathrm{Fe}_{2} \mathrm{SO}_{4}$ & -12.950 & -0.6575 & 0.0860 & -75.271 & 0.00013 \\
\hline$\left(\mathrm{NH}_{4}\right)_{2} \mathrm{SO}_{4}$ & 0.7613 & 0.3807 & 0.0860 & 44.252 & 0.00306 \\
\hline $\mathrm{YNB}$ & 0.5819 & 0.2910 & 0.0860 & 33.824 & 0.01172 \\
\hline $\mathrm{MnSO}_{4} \cdot 1 \mathrm{H}_{2} \mathrm{O}$ & -0.3647 & -0.1824 & 0.0860 & -21.199 & 0.07173 \\
\hline $\mathrm{CuSO}_{4}$ & -0.3039 & -0.1520 & 0.0860 & -17.666 & 0.12064 \\
\hline $\mathrm{KH}_{2} \mathrm{PO}_{4}$ & -0.1044 & -0.0522 & 0.0860 & -0.6070 & 0.56303 \\
\hline $\mathrm{ZnSO}_{4}$ & -0.0577 & -0.0288 & 0.0860 & -0.3352 & 0.74727 \\
\hline $\mathrm{NaCl}$ & -0.0562 & -0.0281 & 0.0860 & -0.3265 & 0.75358 \\
\hline $\mathrm{MgSO}_{4} .7 \mathrm{H}_{2} \mathrm{O}$ & 0.0518 & 0.0259 & 0.0860 & 0.3012 & 0.77199 \\
\hline
\end{tabular}

that they do not contribute to xylitol production (Table 1). It was also observed that the salts $\mathrm{MgSO}_{4}$ and $\mathrm{NaCl}$ did not show statistically significant effects on xylitol production.

The PB design evaluates only which independent variables influence xylitol production. In this case, it can be suggested that $\left(\mathrm{NH}_{4}\right)_{2} \mathrm{SO}_{4}$, yeast extract, YNB, and urea promote improved xylitol production in sugarcane biomass hydrolysate by $C$. tropicalis. Subsequently, a CCD was performed to evaluate the effects of different concentrations of these nitrogen sources on xylitol production. Before this, the effect of variation in medium $\mathrm{pH}$ on yeast performance was evaluated.

\subsection{Effects of medium $\mathrm{pH}$ on xylitol production}

The $\mathrm{pH}$ of fermentation media has been reported as one of the most important factors that affect xylitol production by yeasts (Sampaio et al., 2006). Yeasts usually grow well in acidic medium with $\mathrm{pH}$ between 4.0 and 6.0, though the tolerance range for $\mathrm{pH}$ variation is wide, ranging from pH 2.5 to 8.0 (Cao, Tang, Gong, \& Chen, 1994; Sampaio et al., 2006; Walker, 1998). However, acetic acid present in sugarcane bagasse hydrolysate is a potent inhibitor of yeast metabolism, especially at $\mathrm{pH}$ values below its pKa of 4.75(Almeida et al., 2007; Lawford \& Rousseau, 1993). The optimum pH for xylitol production is species-specific and medium composition-dependent (Hahn-Hägerdal et al., 2007). Thus, in order to evaluate the influence of initial $\mathrm{pH}$ on xylitol production by $\mathrm{C}$. tropicalis JA2, the yeast was inoculated in sugarcane bagasse medium with a final concentration of: $1.0 \mathrm{~g} / \mathrm{L}\left(\mathrm{NH}_{4}\right)_{2} \mathrm{SO}_{4}, 5.0 \mathrm{~g} / \mathrm{L}$ yeast extract, $4.0 \mathrm{~g} / \mathrm{L} \mathrm{YNB}$, and $0.8 \mathrm{~g} / \mathrm{L}$ urea, favorable conditions indicated in the PB design, and $\mathrm{pH}$ adjusted to $4.6,5.5,6.0,6.4$, or 7.0. Xylose consumption and xylitol production were measured after $42 \mathrm{hr}$ of fermentation (Figure 2).

C. tropicalis JA2 consumed all xylose present in the medium after $42 \mathrm{hr}$ of cultivation at $\mathrm{pH}$ 6.4, whereas at $\mathrm{pH} 5.5,6.0$, and 7.0, it consumed approximately $87.5 \%$ of the provided sugar. At $\mathrm{pH} 4.6$, the xylose consumption decreased significantly to $22.0 \%$. The higher xylose consumption correlated with xylitol concentration (Figure 2), and yields, which varied from $0.47 \pm 0.08 \mathrm{~g} / \mathrm{g}$ total xylose at $\mathrm{pH} 6.4$, to $0.19 \pm 0.03 \mathrm{~g} / \mathrm{g}$ total $x y$ lose at $\mathrm{pH}$ 4.6. These observations corroborate previous reports that acetic acid toxicity increases at $\mathrm{pH}$ values below its pKa. Under this condition, acetic acid in its undissociated form penetrates the cell membrane, and once in the cytoplasm, which as a neutral $\mathrm{pH}$, it dissociates, causing toxicity to the cell (Hahn-Hägerdal et al., 2007; Sousa et al., 2012).

Therefore, the results show that $C$. tropicalis JA2 is more efficient for xylitol production in medium containing sugarcane bagasse hydrolysate with an initial $\mathrm{pH}$ of 6.4 .

\subsection{Optimization of xylitol production}

\subsection{1 | Central composite design 1}

To maximize xylitol production, a CCD was carried out with the nitrogen sources that showed significant positive effects on the PB 


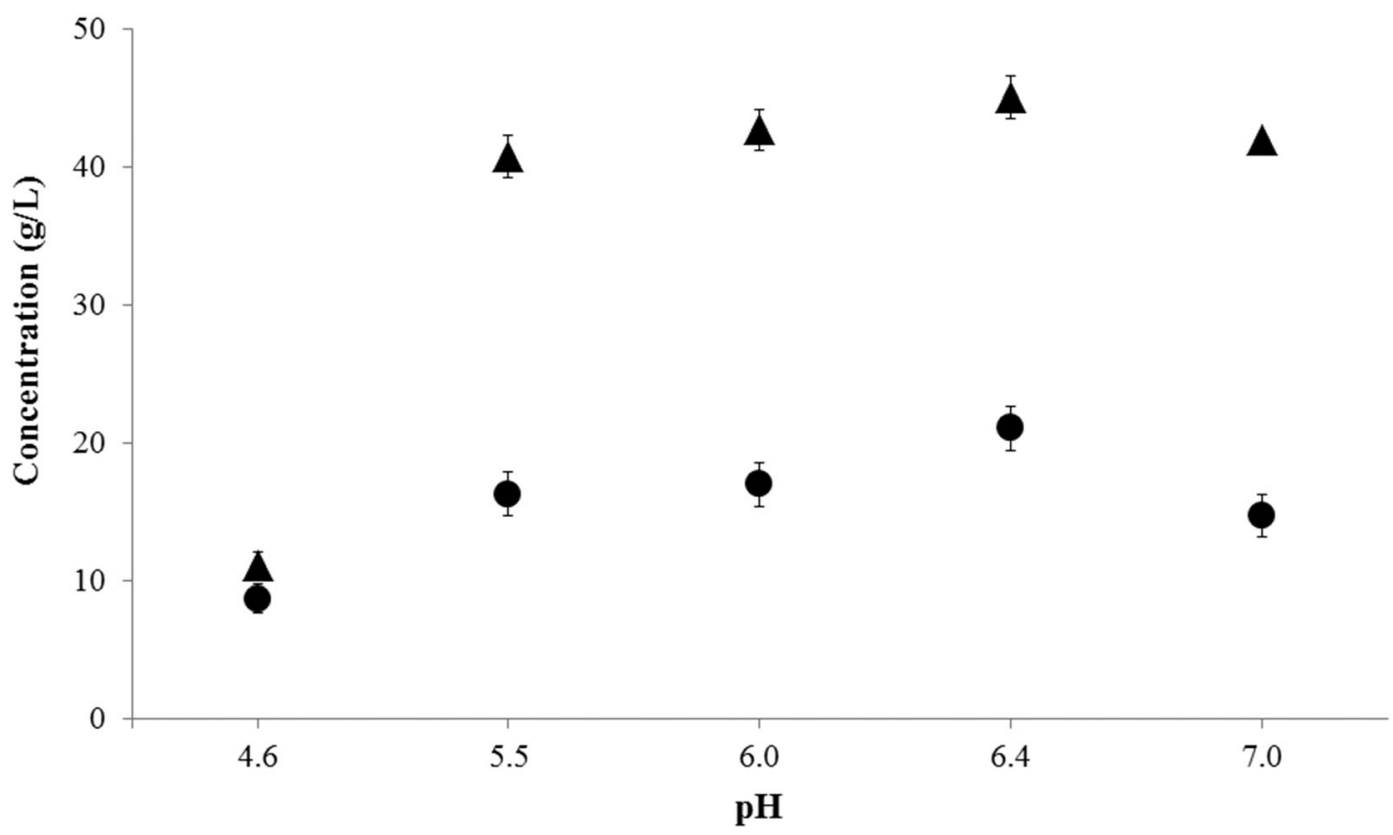

FIGURE 2 Fermentation profile of Candida tropicalis JA2 in hydrolysate medium with different initial pH values, after $42 \mathrm{hr}$ of fermentation. ( $\mathbf{A}$ ) Xylose consumed and ( $)$ xylitol produced. Initial xylose concentration was $50 \mathrm{~g} / \mathrm{L}$. Experiments were performed in triplicate and standard errors are less than $5 \%$

design (( $\left.\mathrm{NH}_{4}\right)_{2} \mathrm{SO}_{4}$, yeast extract, $\mathrm{YNB}$, and urea). Table 2 presents the 27 trials carried out in the design and the experimental values obtained for the responses xylose consumption and xylitol production after $39 \mathrm{hr}$ of fermentation.

The regression equations for xylose consumption and xylitol production with coded variables considering statistically significant parameters $(p<.1)$ are given in Equations 1 and 2, respectively. The analysis of variance indicated that the calculated $F$ value for regressions was highly significant. The $F$ ratio (Fcalc/Ftab) was 5.88 for xylose consumption and 9.42 for xylitol production. The coefficients of determination $\left(R^{2}\right)$ by the models were $75 \%$ and $86 \%$, respectively. Despite the low observed variation for the xylose consumption model, the results predicted by the model are in agreement with experimental values. This happens because the variables and interactions effects are much smaller than the mean in this model. The highest residual value, when the predicted value is subtracted from the observed value for this model, was 1.85 .

Thus, we can conclude that the models fit the experimental data well. The lack of fit was not significant for both models. The value of pure error was low, which indicates good reproducibility of the obtained data. Therefore, it is possible to use techniques for optimization of the responses in the evaluated ranges.

$$
\begin{aligned}
& \text { Xylose consumption }(g / L)= \\
& +0.52+0.78 X_{1}+0.29 X_{2}, 0.48 X_{4}+0.29 X_{4}^{2}, \\
& \\
& \text { Xylitol }(g / L)=18.38-0.99 X_{1}-0.53 X_{2}-1.31 X_{3} \\
& +0.58 X_{4}-0.39 X_{1} X_{4}+0.63 X_{2} X_{3},
\end{aligned}
$$

where, in coded values, $\mathrm{X}_{1}$ corresponds to $\left(\mathrm{NH}_{4}\right)_{2} \mathrm{SO}_{4}, \mathrm{X}_{2}$ to yeast extract, $X_{3}$ to $Y N B$, and $X_{4}$ to urea.
Using the complete models, the eigenvalues and adjustments of the model to the canonical form were determined in order to verify the nature of the stationary point. For both responses, the given values positive and negative values simultaneously, indicating that the inflection point is a saddle. Then, using the models as objective functions and the experimental region as constraints, the maximum in each regression equation was found by a nonlinear iterative numerical solution optimization algorithm, which returns the highest value that the function assumes in the evaluated interval.

For the iterative numerical solution, xylitol production is maximized in medium containing $2.0 \mathrm{~g} / \mathrm{L} \mathrm{YNB}, 4.0 \mathrm{~g} / \mathrm{L}$ urea, and without $\left(\mathrm{NH}_{4}\right)_{2} \mathrm{SO}_{4}$ and yeast extract (in coded values $\mathrm{X}_{1}=-2.0, \mathrm{X}_{2}=-2.0$, $X_{3}=-2.0$, and $X_{4}=2.0$ ). The same maximum condition was found for the xylose consumption model, indicating that the substrate consumption rate and xylitol production are favored by the same nitrogen sources. Replacing the coded values of these parameters in Equation 1, predicted xylitol production is $29.28 \mathrm{~g} / \mathrm{L}$ over $39 \mathrm{hr}$ of fermentation. Equation (2) predicts total xylose consumption. To validate the maximum xylitol production predicted by the model, fermentation was carried out, in triplicate, in medium containing sugarcane bagasse hydrolysate with $7.8 \mathrm{~g} / \mathrm{L}$ acetic acid, xylose concentration of $40.0 \mathrm{~g} / \mathrm{L}$, and $12.0 \mathrm{~g} / \mathrm{L}$ of glucose, supplemented with $2.0 \mathrm{~g} / \mathrm{L}$ YNB, and $4.0 \mathrm{~g} / \mathrm{L}$ urea. After $39 \mathrm{hr}$ of fermentation, $\mathrm{C}$. tropicalis $\mathrm{JA} 2$ produced $28.79 \pm 0.64 \mathrm{~g} / \mathrm{L}$ xylitol (corresponding to a yield of $0.72 \pm 0.05 \mathrm{~g} / \mathrm{g}$ consumed xylose). The xylose was completely consumed. The results obtained experimentally and the small deviations (1.70\%) from the predicted values confirm the quality of the model to fit the data.

It is known that the type and concentration of nitrogen source in the medium play a key role in xylitol production by 
TABLE 2 Central composite design 1 to optimize nitrogen sources concentrations for xylitol production with Candida tropicalis JA2

\begin{tabular}{|c|c|c|c|c|c|c|c|c|}
\hline Tests & \multicolumn{4}{|c|}{ Real variable (coded variable) } & $\begin{array}{l}\text { Xylose } \\
\text { consumption } \\
\text { (g/L) }\end{array}$ & $\begin{array}{l}\text { Xylitol } \\
\text { (g/L) }\end{array}$ & $\begin{array}{l}\text { Yield } \\
(\mathrm{g} / \mathrm{g})\end{array}$ & $\begin{array}{l}\text { Productivity } \\
\text { (g.L.h) }\end{array}$ \\
\hline 1 & $1.5(-1)$ & $2.5(-1)$ & $3.25(-1)$ & $1.0(-1)$ & 36.0 & 20.5 & 0.45 & 0.53 \\
\hline 2 & $1.5(-1)$ & $2.5(-1)$ & $3.25(-1)$ & $3.0(+1)$ & 37.3 & 23.1 & 0.49 & 0.59 \\
\hline 3 & $1.5(-1)$ & $2.5(-1)$ & $5.75(+1)$ & $1.0(-1)$ & 33.7 & 17.5 & 0.40 & 0.45 \\
\hline 6 & $1.5(-1)$ & $7.5(+1)$ & $3.25(-1)$ & $3.0(+1)$ & 36.3 & 21.2 & 0.46 & 0.54 \\
\hline 7 & $1.5(-1)$ & $7.5(+1)$ & $5.75(+1)$ & $1.0(-1)$ & 33.1 & 16.9 & 0.39 & 0.43 \\
\hline 8 & $4.5(+1)$ & $7.5(+1)$ & $5.75(+1)$ & $3.0(+1)$ & 35.4 & 19.3 & 0.42 & 0.49 \\
\hline 9 & $4.5(+1)$ & $2.5(-1)$ & $3.25(-1)$ & $1.0(-1)$ & 32.9 & 21.0 & 0.49 & 0.54 \\
\hline 13 & $4.5(+1)$ & $7.5(+1)$ & $3.25(-1)$ & $1.0(-1)$ & 33.5 & 16.7 & 0.38 & 0.43 \\
\hline 14 & $4.5(+1)$ & $7.5(+1)$ & $3.25(-1)$ & $3.0(+1)$ & 34.1 & 18.6 & 0.42 & 0.48 \\
\hline 15 & $4.5(+1)$ & $7.5(+1)$ & $5.75(+1)$ & $1.0(-1)$ & 33.8 & 17.2 & 0.39 & 0.44 \\
\hline 16 & $4.5(+1)$ & $7.5(+1)$ & $5.75(+1)$ & $3.0(+1)$ & 32.1 & 16.5 & 0.39 & 0.42 \\
\hline 17 & $0.0(-a)$ & $5.0(0)$ & $4.5(0)$ & $2.0(0)$ & 36.1 & 20.3 & 0.44 & 0.52 \\
\hline 18 & $6.0(+a)$ & $5.0(0)$ & $4.5(0)$ & $2.0(0)$ & 33.7 & 16.4 & 0.37 & 0.42 \\
\hline 19 & $3.0(0)$ & $0.0(-a)$ & $4.5(0)$ & $2.0(0)$ & 35.8 & 20.0 & 0.44 & 0.51 \\
\hline 20 & $3.0(0)$ & $10.0(+a)$ & $4.5(0)$ & $2.0(0)$ & 33.0 & 16.6 & 0.39 & 0.42 \\
\hline 27 (C) & $3.0(0)$ & $5.0(0)$ & $4.5(0)$ & $2.0(0)$ & 33.7 & 17.1 & 0.39 & 0.44 \\
\hline
\end{tabular}

Note. Real and coded values for the variables studied (ammonium sulfate, yeast extract, YNB and urea) xylose consumption and xylitol production and experimental yield and productivity (three replicates at the central point) after $39 \mathrm{hr}$ of fermentation.

microorganisms (Barathikannan, Khusro, \& Paul, 2016). Similar to the results reported in this research, previous studies reported an increase in xylose consumption and xylitol production by recombinant Saccharomyces cerevisiae when fermentation medium was supplemented with urea (Tesfaw \& Assefa, 2014). When the fermentation medium was supplemented with urea, the xylitol production by mutant Candida sp. increased up to twofold (Lu, Tsai, Gong, \& Tsao, 1995). Because YNB and urea are expensive compounds when compared with yeast extract (for example), further studies should be carried out to analyze the components of YNB individually, and to evaluate which have the greatest influence on improvement of xylitol production by the yeast $C$. tropicalis JA2.

The model obtained through statistical analysis for cell growth (data not shown) was not significant in the description of the experimental data. The coefficient of determination was low and residues very high. The Pearson correlation coefficient obtained between xylitol production and cell concentration, considering the dry weight, was rho $=0.267$, indicating that there is no correlation between these variables. This behavior showed that yeast growth was not associated with xylitol production and nitrogen source concentration within the range studied in this work.

\subsection{2 | Central composite design 2}

A new CCD2 was carried out with initial xylose and inoculum concentration, and incubation temperature, as independent variables. The responses xylose consumption and xylitol production were measured over $39 \mathrm{hr}$, and results are shown in Table 3.

The models obtained for xylose consumption and xylitol production were statistically significant in the description of the experimental 
TABLE 3 Central composite design 2 to optimize nitrogen sources concentrations for xylitol production with Candida tropicalis JA2

\begin{tabular}{|c|c|c|c|c|c|c|c|}
\hline Tests & \multicolumn{3}{|c|}{ Real variable (coded variable) } & $\begin{array}{l}\text { Xylose } \\
\text { consumption } \\
\text { (g/L) }\end{array}$ & $\begin{array}{l}\text { Xylitol } \\
\text { (g/L) }\end{array}$ & $\begin{array}{l}\text { Yield } \\
\text { (g/g) }\end{array}$ & $\begin{array}{l}\text { Productivity } \\
\text { (g.L·h) }\end{array}$ \\
\hline 1 & $73.6(-1)$ & $9.7(-1)$ & $28.5(-1)$ & 65.1 & 35.9 & 0.65 & 0.92 \\
\hline 2 & $73.6(-1)$ & $9.7(-1)$ & $36.5(+1)$ & 73.0 & 46.9 & 0.64 & 1.20 \\
\hline 3 & $73.6(-1)$ & $20.3(+1)$ & $28.5(-1)$ & 66.3 & 34.6 & 0.52 & 0.89 \\
\hline 6 & $126.4(+1)$ & $9.7(-1)$ & $36.5(+1)$ & 70.3 & 51.5 & 0.73 & 1.32 \\
\hline 7 & $126.4(+1)$ & $20.3(+1)$ & $28.5(-1)$ & 63.5 & 40.0 & 0.63 & 1.03 \\
\hline 8 & $126.4(+1)$ & $20.3(+1)$ & $36.5(+1)$ & 105.1 & 74.0 & 0.70 & 1.90 \\
\hline 9 & $50.0(-a)$ & $15.0(0)$ & $32.5(0)$ & 46.0 & 26.4 & 0.57 & 0.68 \\
\hline 13 & $100.0(0)$ & $15.0(0)$ & $25.0(-a)$ & 57.7 & 30.1 & 0.52 & 0.77 \\
\hline 14 & $100.0(0)$ & $15.0(0)$ & $40.0(+a)$ & 88.2 & 62.7 & 0.71 & 1.61 \\
\hline 15 (C) & $100.0(0)$ & $15.0(0)$ & $32.5(0)$ & 66.0 & 42.6 & 0.64 & 1.09 \\
\hline 16 (C) & $100.0(0)$ & $15.0(0)$ & $32.5(0)$ & 71.1 & 43.3 & 0.61 & 1.11 \\
\hline 17 (C) & $100.0(0)$ & $15.0(0)$ & $32.5(0)$ & 69.9 & 43.9 & 0.63 & 1.13 \\
\hline
\end{tabular}

Note. Real and coded values for the variables studied (xylose, inoculum and temperature) xylose consumption and xylitol production and experimental yield and productivity (three replicates at the central point) after $39 \mathrm{hr}$ of fermentation.

data, and the calculated $F$ value was highly significant for both. The $F$ ratio was 2.96 for xylose consumption and 5.58 for xylitol production, and the regression could be used for predictive purposes (Box, Hunter, \& Hunter, 1978). The lack of fit was not significant, and the value of pure error was low, which indicates good reproducibility of the obtained data, allowing the use of techniques for optimization of the responses in the evaluated ranges.

In the evaluated range for both models, the stationary point is a saddle. Subsequently, we used the nonlinear iterative numerical solution optimization algorithm to find the maximum value for the functions over the studied range. Equations (3) and (4) (empirical equation of second order calculated in the software STATISTICA 12.0, based on the results of CCD2) show the fitted model for xylose consumption and xylitol production after $39 \mathrm{hr}$ of fermentation.

$$
\text { Xylose } \begin{aligned}
(g / L) & =69.23+8.24 X_{2}+9.96 X_{3}+5.79 X_{1} X_{2} \\
& +5.81 X_{1} X_{3},
\end{aligned}
$$

$$
\text { Xylitol } \begin{aligned}
(g / L) & =42.29+10.82 X_{3}+5.65 X_{2}+4.45 X_{1} \\
& +3.03 X_{2} X_{3}+2.93 X_{1} X_{2}+2.71 X_{1} X_{3}+2.66 X_{3}^{2},
\end{aligned}
$$

where, in coded values, $X_{1}$ corresponds to xylose concentration, $X_{2}$ to inoculum concentration, and $X_{3}$ to temperature. The correlation coefficients for the xylitol production model $\left(R^{2}=0.93\right)$ suggest that there is close agreement between the experimental results and the theoretical values predicted by polynomial model. However, the correlation coefficient for the xylose consumption model $\left(R^{2}=0.76\right)$ was below the desired value. There were relative errors of approximately $1 \%$ to $16 \%$, with one case of almost $-36 \%$ for the lowest xylose concentration. This often occurs, but in the region of interest, the relative errors are very low considering processes involving microorganisms (Rodrigues \& lemma, 2012).

Based on Equation (4), xylitol production is maximized in medium with $X_{1}=+1.68 ; X_{2}=0.94$; and $X_{3}=+1.68$, corresponding to $150 \mathrm{~g} / \mathrm{L}$ xylose, inoculating $20 \mathrm{~g} / \mathrm{L}$ of cells, and fermentation carried out at $40^{\circ} \mathrm{C}$. Under these conditions, the model predicts a maximum xylitol production of $97.9 \mathrm{~g} / \mathrm{L}(0.81 \mathrm{~g} / \mathrm{g})$ with productivity of $2.51 \mathrm{~g} \cdot \mathrm{L} \cdot \mathrm{h}$. In the xylose consumption model, the maximum value occurs with initial xylose concentration of $150 \mathrm{~g} / \mathrm{L}$, yeast concentration of $25 \mathrm{~g} / \mathrm{L}$, and temperature at $40^{\circ} \mathrm{C}\left(X_{1}=1.68, X_{2}=1.68\right.$, and $\left.X_{3}=1.68\right)$. Analyzing models and optimum conditions indicated that higher values for independent variables could promote higher response values. After this, a sequential strategy was used to obtain the condition that leads to maximum production and the most appropriate operating conditions. A new CCD (CCD3) was performed with the maximum conditions for xylitol production as a central point. A new range for the variables was proposed and three repetitions at the central point in CCD3 were used in order to validate the previous experiment.

\subsection{3 | Central composite design 3}

The CCD3 experiments were conducted in medium containing sugarcane bagasse hydrolysate diluted to $40 \%(\mathrm{v} / \mathrm{v})$ with glucose 
concentration of $8 \mathrm{~g} / \mathrm{L}$, supplemented with $2.0 \mathrm{~g} / \mathrm{L}$ YNB and $4.0 \mathrm{~g} / \mathrm{L}$ urea, as in previous experiments. In this case, initial xylose concentration $\left(X_{1}\right)$ was evaluated from 80 to $220 \mathrm{~g} / \mathrm{L}$, yeast concentration $\left(X_{2}\right)$ from 10 to $40 \mathrm{~g} / \mathrm{L}$, and temperature $\left(X_{3}\right)$ from $25^{\circ} \mathrm{C}$ to $55^{\circ} \mathrm{C}$. The real and coded values for the variables and the responses xylose consumption and xylitol production are presented in Table 4.

Analyzing the results obtained in the central point experiments (trials 15-17), it was observed that under conditions determined by CCD2, C. tropicalis JA2 yeast would produce $100.3 \pm 1.44 \mathrm{~g} / \mathrm{L}$ xylitol (representing a yield of $0.83 \mathrm{~g} / \mathrm{g}$ of consumed xylose) with a productivity of $2.57 \mathrm{~g} \cdot \mathrm{L} \cdot \mathrm{h}$. The predicted xylose consumption in this condition was $119.25 \mathrm{~g} / \mathrm{L}$, and the experimental value was $119.03 \pm 0.47 \mathrm{~g} / \mathrm{L}$. The results obtained experimentally and the less than $1 \%$ deviation from the predicted values confirm that the models obtained in CCD2 fit the data well.

The regression equations in CCD3 for xylose consumption and xylitol production considering the significant parameters $(p<.1)$ are given in Equations (5) and (6), respectively.

$$
\begin{aligned}
& \text { Xylose }(g / L)=113.35-33.80 X_{3}^{2}+18.13 X_{1} \\
& +15.68 X_{2}-13.48 X_{3}-10.83 X_{1}^{2}-10.52 X_{2}^{2}, \\
& \begin{aligned}
\text { Xylitol }(g / L) & =101.46-29.14 X_{3}^{2}+13.22 X_{1} \\
& +10.39 X_{2}-10.14 X_{1}^{2}-9.26 X_{2}^{2}-5.77 X_{3},
\end{aligned}
\end{aligned}
$$

where, in coded values, $X_{1}$ corresponds to xylose concentration, $X_{2}$ to inoculum concentration, and $X_{3}$ to temperature.
The analysis of variance corresponding to xylose consumption and xylitol production after $39 \mathrm{hr}$ fermentation indicates that the explained variances $\left(R^{2}=0.94\right.$ and 0.93 , respectively) and $F$ calc (30.61 and 20.69 , respectively) are suitable to evaluate the tendency of this response. The calculated $F$ value was six times greater than the value tabulated for $F$ for both models.

The models are statistically significant and show good agreement between experimental and predicted results. The sum of squares for pure error was low, which indicates good reproducibility of the obtained data.

Using the complete model for xylitol production response, the eigenvalues and adjustments of the model for the canonical form were determined to verify the nature of the stationary point, which presented only negative values, indicating a maximum point that corresponds to $177 \mathrm{~g} / \mathrm{L}$ xylose, $30 \mathrm{~g} / \mathrm{L}$ of inoculum, and $39.3^{\circ} \mathrm{C}$ $\left(X_{1}=0.66, X_{2}=0.58\right.$, and $\left.X_{3}=-0.09\right)$. Substituting the coded values of these parameters into Equation 5 results in a predicted xylitol production of $108.96 \mathrm{~g} / \mathrm{L}(0.86 \mathrm{~g} / \mathrm{g})$ with productivity of $2.79 \mathrm{~g} \cdot \mathrm{L} \cdot \mathrm{h}$ after $39 \mathrm{hr}$ of fermentation. The maximum stationary point was also found in the xylose consumption model when $X_{1}=0.94, X_{2}=0.88$, and $X_{3}=-0.17$, corresponding to $189.1 \mathrm{~g} / \mathrm{L}$ of xylose, $32.83 \mathrm{~g} / \mathrm{L}$ of inoculum, and $38.5^{\circ} \mathrm{C}$. In this condition, predicted xylose consumption is $130.00 \mathrm{~g} / \mathrm{L}$. We can observe that the maximum conditions for both models are very similar.

The results obtained from CCD3 were experimentally verified at optimal xylitol production conditions. The xylose concentration was $177 \mathrm{~g} / \mathrm{L}$, inoculum with $30.0 \mathrm{~g} / \mathrm{L}$ cells, and fermentation at

TABLE 4 Central composite design 3 to optimize nitrogen sources concentrations for xylitol production with Candida tropicalis JA2

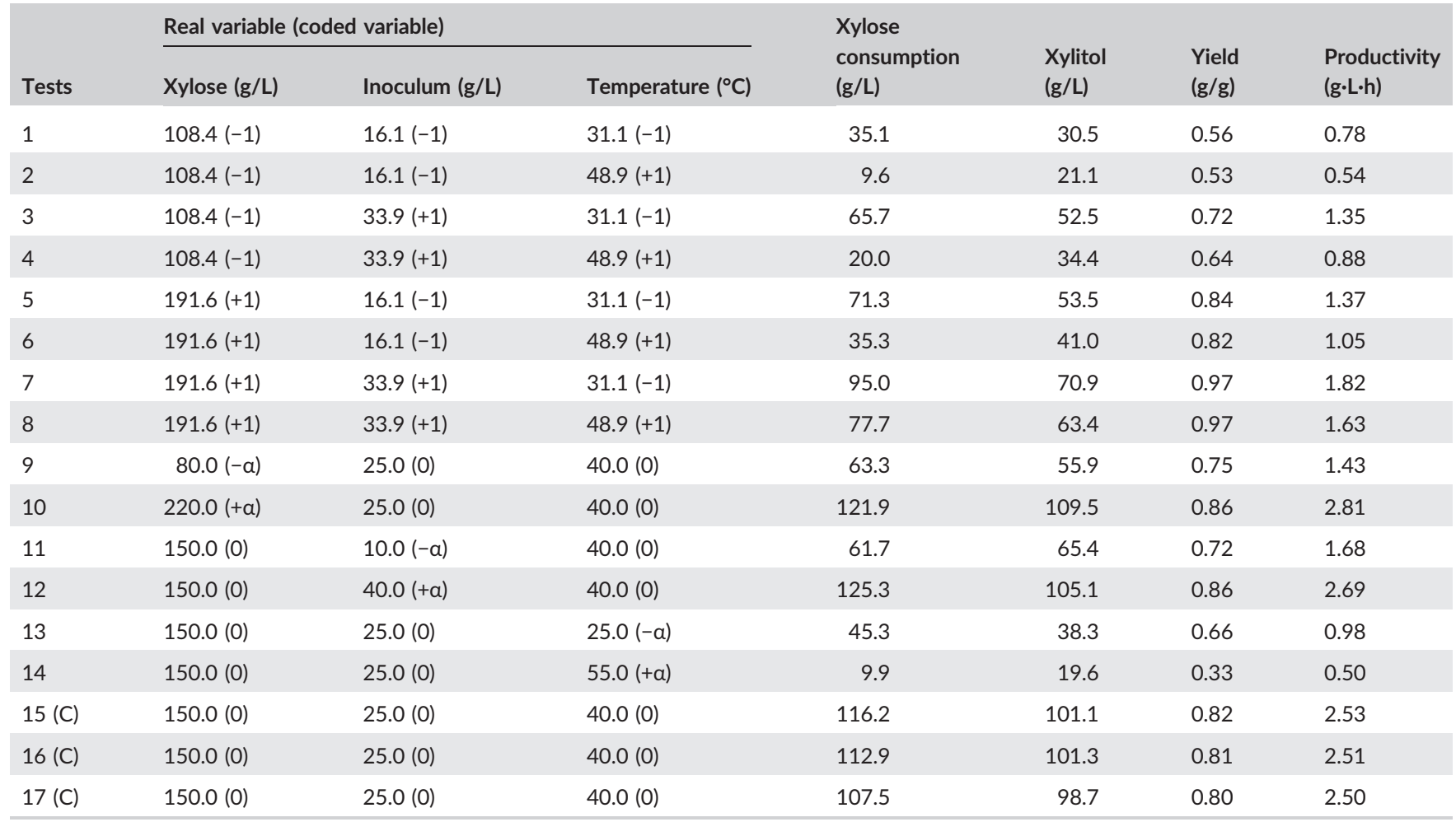

Note. Real and coded values for the variables studied (xylose, inoculum and temperature) xylose consumption and xylitol production and experimental yield and productivity (three replicates at the central point) after $39 \mathrm{hr}$ of fermentation. 
TABLE 5 Xylitol production by different yeasts on different substrates

\begin{tabular}{|c|c|c|c|c|c|c|}
\hline Feedstocks & Microorganisms & $\begin{array}{l}\text { Acetic acid } \\
\text { (g/L) }\end{array}$ & $\begin{array}{l}\text { Xylitol } \\
\text { (g/L) }\end{array}$ & $\begin{array}{l}\text { Xylitol yield } \\
\text { (g/g xylose) }\end{array}$ & $\begin{array}{l}\text { Productivity } \\
\text { (g.L.h) }\end{array}$ & Reference \\
\hline Corncob hydrolysate & Candida tropicalis W103 & 1.00 & 68.4 & 0.70 & 0.95 & Cheng et al. (2009) \\
\hline Acid hydrolysate from olive pruning & C. tropicalis NBRC 0618 & - & 9.0 & 0.23 & 0.06 & Mateo et al. (2015) \\
\hline Rice straw & C. tropicalis & - & 1.8 & 0.19 & 0.06 & Swain and Krishnan (2015) \\
\hline Sugarcane straw & $\begin{array}{l}\text { Candida guilliermondii FTI } \\
\quad 20037\end{array}$ & 2.87 & 17.0 & 0.41 & 0.34 & $\begin{array}{l}\text { Hernández-Perez et al. } \\
\text { (2016) }\end{array}$ \\
\hline Corncob hemicellulosic hydrolysate & C. tropicalis & - & 58.8 & 0.77 & 2.45 & Jia et al. (2016) \\
\hline $\begin{array}{l}\text { Hemicellulosic liquor from sugarcane } \\
\text { bagasse }\end{array}$ & C. tropicalis & 1.39 & 81.6 & 0.57 & 0.68 & Vallejos et al. (2016) \\
\hline
\end{tabular}

$40^{\circ} \mathrm{C}$. After $39 \mathrm{hr}$ of fermentation, C. tropicalis JA2 produced $109.5 \pm 0.63 \mathrm{~g} / \mathrm{L}$ xylitol, with a yield of $0.86 \pm 0.04 \mathrm{~g} / \mathrm{g}$ of consumed xylose and productivity of $2.81 \pm 0.01 \mathrm{~g} \cdot \mathrm{L} \cdot \mathrm{h}$. For this condition, a xylose consumption of $128.01 \mathrm{~g} / \mathrm{L}$ was predicted, and up to $127.32 \pm 4.1 \mathrm{~g} / \mathrm{L}$ xylose was experimentally consumed. During the fermentations, the concentrations of acetic acid and glycerol were also monitored, and it was observed that the values did not change considerably. The small deviations from the predicted values confirmed that the models developed could reliably predict xylose and xylitol concentration.

Finally, C. tropicalis JA2 performance was evaluated in nondiluted hydrolysate. For this, a fermentation experiment was carried out with $100 \%$ sugarcane biomass hydrolysate, containing approximately $80 \mathrm{~g} / \mathrm{L}$ xylose and $18 \mathrm{~g} / \mathrm{L}$ acetic acid. After $40 \mathrm{hr}$, the yeast $\mathrm{C}$. tropicalis JA2 was able to produce $41.5 \pm 1.3 \mathrm{~g} / \mathrm{L}$ xylitol, with a yield of $0.95 \pm 0.04 \mathrm{~g} / \mathrm{g}$ of consumed xylose, and productivity of $1.04 \pm 0.03 \mathrm{~g} \cdot \mathrm{L} \cdot \mathrm{h}$ (Table 5). For this condition, up to $43.6 \pm 1.5 \mathrm{~g} / \mathrm{L}$ xylose was consumed. The hydrolysate toxicity, which has a very high concentration of acetic acid, reduced the amount of xylose consumed (from $71 \%$ to $53 \%$ ) and productivity (from 2.81 to $1.04 \mathrm{~g} / \mathrm{L} . \mathrm{h}$ ) when compared with the previous experiments. However, the xylitol yield increased from 0.86 to $0.95 \mathrm{~g} / \mathrm{g}$ of consumed xylose (Table 5). The inhibitory effects of the hydrolysate completely hampered yeast growth (data not shown), and the carbon was directed almost exclusively to xylitol production. These results confirm the potential of $C$. tropicalis JA2 to produce xylitol even in hydrolysates with very high concentration of acetic acid (Table 5).

Optimization of the medium composition and the fermentation parameters by three sequential CCDs allowed a significant improvement in xylitol production by the new isolated $C$. tropicalis JA2 strain. Indeed, it was possible to increase xylitol production from $11.2 \pm 0.02 \mathrm{~g} / \mathrm{L}$ xylitol (0.47 $\pm 0.03 \mathrm{~g} / \mathrm{g}$ consumed xylose) to $109.5 \pm 0.63 \mathrm{~g} / \mathrm{L}(0.86 \pm 0.04 \mathrm{~g} / \mathrm{g}$ consumed xylose). These results show the promising performance of $C$. tropicalis JA2 for xylitol production in media containing sugarcane bagasse hydrolysate. Indeed, the high xylitol yield of0.86 $\pm 0.04 \mathrm{~g} / \mathrm{g}$ of consumed xylose and productivity of $2.81 \pm 0.01 \mathrm{~g} \cdot \mathrm{L} \cdot \mathrm{h}$ obtained in this study are among the best results reported for microbial production of xylitol, especially when using biomass hydrolysate with high content of acetic acid (Table 5).

C. tropicalis CCTCC M2012462 was able to produce xylitol with yields of $0.72 \mathrm{~g} / \mathrm{g}$ of consumed xylose; however, this was only after $60 \mathrm{hr}$ of fermentation and in a medium containing corn straw biomass hydrolysate with only $3.93 \mathrm{~g} / \mathrm{L}$ acetic acid (Wang, Ling, \& Zhao, 2015). The xylitol concentration values obtained are higher than those found by Jia et al. (2016), who obtained $0.77 \mathrm{~g} / \mathrm{g}$ of consumed xylose and productivity of $2.45 \mathrm{~g} \cdot \mathrm{L} \cdot \mathrm{h}$ after $40 \mathrm{hr}$ of fermentation, using corncob hydrolysate as substrate. They are also higher than the value found by Vallejos et al. (2016), who achieved a maximum xylitol production of $0.57 \mathrm{~g} / \mathrm{g}$, after $120 \mathrm{hr}$, produced by C. tropicalis in liquor obtained from sugarcane bagasse with $1.39 \mathrm{~g} / \mathrm{L}$ acetic acid. Finally, Albuquerque et al. (2015) reported a maximum xylitol production of $0.36 \mathrm{~g} /$ gand productivity of $0.11 \mathrm{~g} \cdot \mathrm{L} \cdot \mathrm{h}$ by Kluyveromyces marxianus in cashew apple bagasse hydrolysate with $4.5 \mathrm{~g} / \mathrm{L}$ acetic acid.

\section{4 | CONCLUSIONS}

The strategy used to select a non-Saccharomyces yeast strain tolerant to a hydrolysate with high acetic acid concentration was successful, because the newly identified $C$. tropicalis strains showed promising results for xylitol production on sugarcane biomass hydrolysate. The optimization of the fermentation parameters $(\mathrm{pH}$, salt, and nitrogen sources, inoculum and xylose concentration, and temperature of fermentation) allowed a considerable increase in xylitol production from $11.20 \pm 1.47$ to $109.5 \pm 0.63 \mathrm{~g} / \mathrm{L}$ and yield from $0.47 \pm 0.03$ to $0.86 \pm 0.04 \mathrm{~g} / \mathrm{g}$. Higher yield and productivity 
values were observed when the hydrolysate was supplemented with $2.0 \mathrm{~g} / \mathrm{L}$ YNB and $4.0 \mathrm{~g} / \mathrm{L}$ urea, and fermentation was carried out with inoculum of $30 \mathrm{~g} / \mathrm{L}, 177 \mathrm{~g} / \mathrm{L}$ xylose, at $\mathrm{pH}$ 6.4, and at $40^{\circ} \mathrm{C}$.

\section{ACKNOWLEDGEMENTS}

The authors wish to thank the Sugarcane Technology Center (CTC) and the Brazilian Development Bank (BNDES) for financial support.

\section{ORCID}

Wilson G. Morais Junior (DD https://orcid.org/0000-0002-2530-6327

João R.M. Almeida (1D https://orcid.org/0000-0002-2902-5805

\section{REFERENCES}

Aguirre-Zero, O., Zero, D. T., \& Proskin, H. M. (1993). Effect of chewing xylitol chewing gum on salivary flow rate and the acidogenic potential of dental plaque. Caries Research, 27, 55-59. https://doi.org/10.1159/ 000261516

Albuquerque, T. L., Gomes, S. D. L., Marques, J. E. Jr., Silva, I. J. Jr., \& Rocha, M. V. P. (2015). Xylitol production from cashew apple bagasse by Kluyveromyces marxianus CCA510. Catalysis Today, 255, 33-40. https://doi.org/10.1016/j.cattod.2014.10.054

Almeida, J. R., Karhumaa, K., Bengtsson, O., \& Gorwa-Grauslund, M. F. (2009). Screening of Saccharomyces cerevisiae strains with respect to anaerobic growth in non-detoxified lignocellulose hydrolysate. Bioresource Technology, 100(14), 3674-3677. https://doi.org/10.1016/ j.biortech.2009.02.057

Almeida, J. R. M., Modig, T., Petersson, A., Hähn-Hägerdal, B., Lidén, G., \& Gorwa-Grauslund, M. F. (2007). Increased tolerance and conversion of inhibitors in lignocellulosic hydrolysates by Saccharomyces cerevisiae. Journal of Chemical Technology and Biotechnology, 82, 340-349. https://doi.org/10.1002/jctb.1676

Arruda, P. V., Rodrigues, R. D. C. L. B., Silva, D. D. V., \& Felipe, M. D. G. D. A. (2011). Evaluation of hexose and pentose in pre-cultivation of Candida guilliermondii on the key enzymes for xylitol production in sugarcane hemicellulosic hydrolysate. Biodegradation, 22, 815-822. https://doi.org/10.1007/s10532-010-9397-1

Barathikannan, K., Khusro, A., \& Paul, A. (2016). Simultaneous production of xylitol and ethanol from different hemicellulose waste substrates by Candida tropicalis strain LY15. Journal of Bioprocessing \& Biotechniques, 6(7), 289-296.

Bazoti, S. F., Golunski, S., Siqueira, D. P., Scapini, T., Barrilli, E. T., Mayer, D. A., ... Treichel, H. (2017). Second-generation ethanol from nondetoxified sugarcane hydrolysate by a rotting wood isolated yeast strain. Bioresource Technology, 244(1), 582-587. https://doi.org/ 10.1016/j.biortech.2017.08.007

Bier, M. C. J., Maranho, L. T., Azevedo, J. A. M., \& da Silva, L. S. J. (2007). Crescimento e consumo de xilose de Candida guilliermondii na fermentação submersa utilizando-se bagaço de cana-de-açúcar. Evid, 7(2), 119-130.

Box, G., Hunter, W. G., \& Hunter, J. S. (1978). Statistics for experimenters: Design, innovation, and discovery. New York: John Wiley \& Sons.

Cadete, R. M., de las Heras, A. M., Sandstrom, A. G., Ferreira, G., Gírio, F., Gorwa-Grauslund, M. F., ... Fonseca, C. (2016). Exploring xylose metabolism in Spathaspora species: XYL1.2 from Spathaspora passalidarum as the key for efficient anaerobic xylose fermentation in metabolic engineered Saccharomyces cerevisiae. Biotechnology for Biofuels, 9, 167. https://doi.org/10.1186/s13068-016-0570-6
Cao, N. J., Tang, R., Gong, C. S., \& Chen, L. F. (1994). The effect of cell density on the production of xylitol from D-xylose by yeasts. Applied Biochemistry and Biotechnology, 45-46, 515-559.

Carvalheiro, F., Duarte, L. C., Medeiros, R., \& Gírio, F. M. (2007). Xylitol production by Debaryomyceshansenii in brewery spent grain diluteacid hydrolysate: Effect of supplementation. Biotechnology Letters, 29, 1887-1891. https://doi.org/10.1007/s10529-007-9468-5

Cheng, K. K., Zhang, J. A., Ling, H. Z., Ping, W. X., Huang, W., Ge, J. P., \& Xu, J. P. (2009). Optimization of $\mathrm{pH}$ and acetic acid concentration for bioconversion of hemicelluloses from corncobs to xylitol by Candida tropicalis. Biochemical Engineering Journal, 43, 203-207. https://doi. org/10.1016/j.bej.2008.09.012

Dasgupta, D., Bandhu, S., Adhikari, D. K., \& Ghosh, D. (2017). Challenges and prospects of xylitol production with whole cell bio-catalysis: A review. Microbiological Research, 197, 9-21. https://doi.org/10.1016/ j.micres.2016.12.012

De Mello Lourenço, M. V., Dini-Andrade, F., Aguilar-Vildoso, C., \& Basso, L. C. (2014). Biotechnological potential of Candida spp. for the bioconversion of D-xylose to xylitol. African Journal of Microbiology Research, 8(20), 2030-2036.

García-Diéguez, C., Salgado, J. M., Roca, E., \& Domínguez, J. M. (2001). Kinetic modelling of the sequential production of lactic acid and xylitol from vine trimming wastes. Bioprocess and Biosystems Engineering, 34, 869-878.

Guo, X., Zhang, R., Li, Z., Dai, D., Li, C., \& Zhou, X. (2013). A novel pathway construction in Candida tropicalis for direct xylitol conversion from corncob xylan. Bioresource Technology, 128, 547-552. https://doi.org/ 10.1016/j.biortech.2012.10.155

Haaland, P. D. (1989). Experimental design in biotechnology. New York: Marcel Dekker Inc.

Hahn-Hägerdal, B., Karhumaa, K., Fonseca, C., Spencer-Martins, I., \& GorwaGrauslund, M. F. (2007). Towards industrial pentose-fermenting yeast strains. Applied Microbiology and Biotechnology, 74(5), 937-953. https://doi.org/10.1007/s00253-006-0827-2

Hernández-Perez, A. F., Arruda, P. V., \& Felipe, M. G. A. (2016). Sugarcane straw as a feedstock for xylitol production by Candida guilliermondii FTI 20037. Brazilian Journal of Microbiology, 47, 489-496. https://doi.org/ 10.1016/j.bjm.2016.01.019

Hongzhi, L., Keke, C., Jingping, G., \& Wenxiang, P. (2011). Statistical optimization of xylitol production from corncob hemicellulose hydrolysate by Candida tropicalis HDY-02. Nature Biotechnology, 28, 673-678.

Imark, S., Canisag, H., Vokoun, C., \& Meryemoglu, B. (2017). Xylitol production from lignocellulosic: Are corn biomass residues good candidates? Biocatalysis and Agricultural Biotechnology, 11, 220-223.

Jia, H., Shao, T., Zhong, C., Li, H., Jiang, M., Zhou, H., \& Wei, P. (2016). Evaluation of xylitol production using corncob hemicellulose hydrolysate by combining tetra-butylammonium hydroxide extraction with dilute acid hydrolysis. Carbohydrate Polymers, 151, 676-683. https://doi.org/ 10.1016/j.carbpol.2016.06.013

Karhumaa, K., Garcia-Sanchez, R., Hahn-Hägerdal, B., \& Gorwa-Grauslund, M. F. (2007). Comparison of the xylose reductase-xylitol dehydrogenase and the xylose isomerase pathways for xylose fermentation by recombinant Saccharomyces cerevisiae. Microbial Cell Factories, 6, 5. https://doi.org/10.1186/1475-2859-6-5

Kumar, A. K., \& Sharma, S. (2017). Recent updates on different methods of pretreatment of lignocellulosic feedstocks: A review. Bioresources and Bioprocessing https://doi.org/10.1186/2017/s40643-017-0137-9, 4, 7.

Kurtzman, C. P., \& Robnett, C. J. (1998). Identification and phylogeny of ascomycetous yeasts from analysis of nuclear large subunit (26S) ribosomal DNA partial sequences. Antonie Van Leeuwenhoek, 73, 331-371. https://doi.org/10.1023/A:1001761008817 
Lawford, H. G., \& Rousseau, J. D. (1993). The effect of acetic acid on fuel ethanol production by Zymomonas. Applied Biochemistry and Biotechnology, 39-40, 687-699. https://doi.org/10.1007/BF02919028

Liaw, W. C., Chen, C. S., Chang, W. S., \& Chen, K. P. (2008). Xylitol production from rice straw hemicellulose hydrolysate by polyacrylic hydrogel thin films with immobilized Candida subtropicalis WF79. Journal of Bioscience and Bioengineering, 105, 97-105. https://doi.org/10.1263/jbb.105.97

Ling, H., Cheng, K., Ge, J., \& Ping, W. (2011). Statistical optimization of xylitol production from corncob hemicellulose hydrolysate by Candida tropicalis HDY-02. New Biotechnology, 28, 673-678. https://doi.org/ 10.1016/j.nbt.2010.05.004

Lu, J., Tsai, L. B., Gong, C. S., \& Tsao, G. T. (1995). Effect of nitrogen sources on xylitol production from D-xylose by Candida sp. L-102. Biotechnology Letters, 17, 67-170.

Lynch, H., \& Milgrom, P. (2003). Xylitol and dental caries: An overview for clinicians. Journal of the California Dental Association, 31, 205-209.

Mateo, S., Puentes, J. G., Moya, A. J., \& Sánchez, S. (2015). Ethanol and xylitol production by fermentation of acid hydrolysate from olive pruning with Candida tropicalis NBRC 0618. Bioresource Technology, 190, 1-6. https://doi.org/10.1016/j.biortech.2015.04.045

Misra, S., Raghuwanshi, S., \& Saxena, R. K. (2013). Evaluation of corncob hemicellulosic hydrolysate for xylitol production by adapted strain of Candida tropicalis. Carbohydrate Polymers, 92, 1596-1601. https://doi. org/10.1016/j.carbpol.2012.11.033

Miura, M., Watanabe, I., Shimotori, Y., Aoyama, M., Kojima, Y., \& Kato, Y. (2013). Microbial conversion of bamboo hemicellulose hydrolysate to xylitol. Wood Science and Technology, 47, 515-522. https://doi.org/ 10.1007/s00226-012-0501-z

Ping, Y., Ling, H. Z., Song, G., \& Ge, J. P. (2013). Xylitol production from non-detoxified corncob hemicellulose acid hydrolysate by Candida tropicalis. Biochemical Engineering Journal, 75, 86-91. https://doi.org/ 10.1016/j.bej.2013.03.022

Plackett, R. L., \& Burmam, J. P. (1946). The design of optimum multifactorial experiments. Biometrika, 33(4), 305-325. https://doi.org/10.1093/ biomet/33.4.305

Prakash, G., Varma, A. J., Prabhune, A., Shouche, Y., \& Rao, M. (2011). Microbial production of xylitol from d-xylose and sugarcane bagasse hemicellulose using newly isolated thermotolerant yeast Debaryomyceshansenii. Bioresource Technology, 102, 3304-3308. https://doi.org/10.1016/j.biortech.2010.10.074

Rafiqul, I. S., Sakinah, A. M., \& Zularisam, A. W. (2015). Inhibition by toxic compounds in the hemicellulosic hydrolysates on the activity of xylose reductase from Candida tropicalis. Biotechnology Letters, 37(1), 191-196. https://doi.org/10.1007/s10529-014-1672-5

Rao, R. S., Jyothi, C. H. P., Prakasham, R. S., Sarma, P. N., \& Rao, L. V. (2006). Xylitol production from corn fiber and sugarcane bagasse hydrolysates by Candida tropicalis. Bioresource Technology, 97, 1974-1978. https://doi.org/10.1016/j.biortech.2005.08.015

Rocha, M. V. P., Rodrigues, T. H. S., Albuquerque, T. L., Gonçalves, L. R. B., \& Macedo, G. R. (2014). Evaluation of dilute acid pretreatment on cashew apple bagasse for ethanol and xylitol production. Chemical Engineering Journal, 243, 234-243. https://doi.org/10.1016/j.cej.2013.12.099

Rodrigues, M. I., \& lemma, A. F. (2012). Experimental design and process optimization. Campinas, Brazil: Cárita Editora.

Rodrigues, R. C. L. B., Kenealy, W. R., \& Jeffries, T. W. (2011). Xylitol production from DEO hydrolysate of corn stover by Pichia stipitis YS-30. Journal of Industrial Microbiology \& Biotechnology, 38, 1649-1655. https://doi.org/10.1007/s10295-011-0953-4

Ronda, F., Gómez, M., Blanco, C. A., \& Caballero, P. A. (2005). Effects of polyols and non-digestible oligosaccharides on the quality of sugar- free sponge cakes. Food Chemistry, 90, 549-555. https://doi.org/ 10.1016/j.foodchem.2004.05.023

Sampaio, F. C., Moraes, C. A., Faveri, D. D., Perego, P., Converti, A., \& Passos, F. M. L. (2006). Influence of temperature and $\mathrm{pH}$ on xylitol production from xylose by Debaryomyceshansenii UFV-170. Process Biochemistry, 41, 675-681. https://doi.org/10.1016/j.procbio.2005.08.019

Sousa, M. J., Ludovico, P., Rodrigues, F., Leão, C., \& Côrtes-Real, M. (2012). Chapter 4-Stress and cell death in yeast induced by acetic acid. Cell Metabolism: Cell homeostasis and stress response (pp. 73-100). London, UK: IntechOpen.

Swain, M. R., \& Krishnan, C. (2015). Improved conversion of rice straw to ethanol and xylitol by combination of moderate temperature ammonia pretreatment and sequential fermentation using Candida tropicalis. Industrial Crops and Products, 77, 1039-1046. https://doi.org/10. 1016/j.indcrop.2015.10.013

Tesfaw, A., \& Assefa, F. (2014). Current in bioethanol production by Saccharomyces cerevisae: Substrate, inhibitor reduction, growth variables, coculture and immobilization. International Scholarly Research Notices, 2014, 1-11. https://doi.org/10.1155/2014/532852

Trichez, D., Steindorff, A. S., Soares, C. E. V. F., Formighieri, E. F., \& Almeida, J. R. M. (2018). Physiological and comparative genomic analysis of new yeasts Spathaspora sp. JA1 and Meyerozyma caribbica JA9 reveal insights into xylitol production. FEMS Yeast Research. (submitted/under review)

Vallejos, M. E., Chade, M., Mereles, E. B., Bengoechea, D. I., Brizuela, J. G., Felissia, F. E., \& Area, M. C. (2016). Strategies of detoxification and fermentation for biotechnological production of xylitol from sugarcane bagasse. Industrial Crops and Products, 91, 161-169. https://doi.org/ 10.1016/j.indcrop.2016.07.007

Walker, G. M. (1998). Yeast Physiology and Biochemistry. John Wiley \& Sons, Chichester.

Wang, L., Yang, M., Fan, X., Zhu, X., Xu, T., \& Yuan, Q. (2011). An environmentally friendly and efficient method for xylitol bioconversion with high-temperature steaming corncob hydrolysate by adapted Candida tropicalis. Process Biochemistry, 46, 1619-1626. https://doi.org/ 10.1016/j.procbio.2011.05.004

Wang, W., Ling, H., \& Zhao, H. (2015). Steam explosion pretreatment of corn straw on xylose recovery and xylitol production using hydrolysate without detoxification. Process Biochemistry, 50, 1623-1628. https:// doi.org/10.1016/j.procbio.2015.06.001

Werpy, T., \& Petersen, G. (2004). Top value added chemicals from biomass: Volume I - Results of screening for potential candidates from sugars and synthesis gas. United States: The Pacific Northwest National Laboratory (PNNL) and the National Renewable Energy Laboratory (NREL). doi:10.2172/15008859

Xu, Y. X., \& Hanna, M. A. (2010). Optimum conditions for dilute acid hydrolysis of hemicellulose in dried distillers grains with solubles. Industrial Crops and Products, 32, 511-517. https://doi.org/10.1016/j.indcrop. 2010.06.024

Zhang, J., Geng, A., Yao, C., Lu, Y., \& Li, Q. (2012). Xylitol production from $\mathrm{d}$-xylose and horticultural waste hemicellulosic hydrolysate by a new isolate of Candida athensensis SB18. Bioresource Technology, 105, 134-141. https://doi.org/10.1016/j.biortech.2011.11.119

How to cite this article: Morais Junior WG, Pacheco TF, Trichez D, Almeida JRM, Gonçalves SB. Xylitol production on sugarcane biomass hydrolysate by newly identified Candida tropicalis JA2 strain. Yeast. 2019;36:349-361. https://doi. org/10.1002/yea.3394 